\title{
Social Responsibility For Faculty: An Example Of Faculty Involvement-Part I
}

J. Patrick McLaughlin, Northwest Missouri State University, USA John W. Baker, Jr., Northwest Missouri State University, USA

\begin{abstract}
Social responsibility is a concept often used to describe how large corporations, or even small businesses, should "give back" something to the communities that they serve. We feel the same is true when it comes to faculty members. Oftentimes, the greatest expertise in a given subject area in a community is housed within the confines of the faculty members of the local college or university and such knowledge and expertise can be shared in a plethora of venues as part of the "service" component of their annual evaluation. Our paper sets forth an example of such faculty involvement in an attempt to improve the decision-making of our incoming students and, as a result, the overall community by providing a presentation to our Freshman Seminar courses on the legal ramifications of poor decision-making as they begin to manage their newfound freedom of choices. In our paper, we point out the pedagological system that we use to emphasize the importance of making the right choices for now, which will clearly have a direct effect upon their future.
\end{abstract}

Keywords: Social Responsibility, Faculty Service, Effects of Underage Drinking, Costs of Underage Drinking, Behavior Modification.

\section{INTRODUCTION}

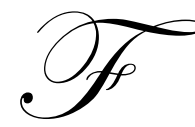

aculty members in higher education are most often evaluated annually under three main categories: competence in teaching, scholarly activities, and service. While all three areas are indeed important, one that may be overlooked is service to your community.

College and university faculty possess a tremendous amount of formal education and practical experience in their given areas of expertise. Said background can easily be shared with adults and youth alike to help answer questions, give direction, and provide insight into becoming better and more knowledgeable citizens.

Such is the case in this paper. We will provide you with just one example of how we are being "socially responsible" by giving back to our students and community via a presentation to new freshmen who will be away from home, for many, the first time and will be responsible for making their own choices and decisions on what type of person they shall be, especially when it comes to social relationships. Thus, we put together a Freshman Seminar presentation for a group of approximately 100 incoming freshman students at Northwest. It is a one-hour course designed to provide them with an orientation to "college life", and includes topics such as advisement, study skills, basic budgeting, opportunities on campus, decision-making, making the right choices, and the legal and financial ramifications of making the wrong choices.

\section{What's the Problem?}

Why do we feel it is important for us to point out these issues to young people? Because research and statistics show how underage drinking and drug use affect not only the students directly, but also their families and ultimately the entire community.

For instance, Table 1 lists some frightening statistics that reveal just how important these community and societal issues are. 
"Underage drinking cost the citizens of Missouri $\$ 1.3$ billion in 2005. These costs include medical care, work loss, and pain and suffering associated with the multiple problems resulting from the use of alcohol by youth.",

In fact, as illustrated by the following table, there are a substantial number of negative factors listed which result in this tremendous cost, just in the State of Missouri alone.

Table 1: "Costs of Underage Drinking by Problem, Missouri 2005"

\begin{tabular}{|l|c|}
\hline \multicolumn{1}{|c|}{ Problem } & $\begin{array}{c}\text { Total Costs } \\
\text { (in millions) }\end{array}$ \\
\hline Youth Violence & $\$ 664.5$ \\
\hline Youth Traffic Crashes & $\$ 327.6$ \\
\hline High-Risk Sex, Ages 14-20 & $\$ 126.9$ \\
\hline Youth Property Crime & $\$ 66.8$ \\
\hline Youth Injury & $\$ 51.8$ \\
\hline Poisonings and Psychoses & $\$ 10.2$ \\
\hline FAS Among Mothers Age 15-20 & $\$ 24.2$ \\
\hline Youth Alcohol Treatment & $\$ 25.6$ \\
\hline Total & $\mathbf{\$ 1 , 2 9 7 . 6}$ \\
\hline
\end{tabular}

\section{Alcohol Consumption by Youth in Missouri}

"Underage drinking is widespread in Missouri. Approximately 249,000 underage youth in Missouri drink each year. " In 2005, following are statistics from self-reports by Missouri students in grades 9-12:.

- $\quad 72 \%$ had at least one drink of alcohol on one or more days during their life.

- $\quad 24 \%$ had their first drink of alcohol, other than a few sips, before age 13.

- $\quad 41 \%$ had at least one drink of alcohol on one or more occasion in the past 30 days.

- $\quad 25 \%$ had five or more drinks of alcohol in a row (i.e. binge drinking) in the past 30 days.

- $\quad 3 \%$ had at least one drink of alcohol on school property on one or more of the past 30 days.

In 2005, underage drinkers consumed 16.9\% of all alcohol sold in Missouri, totaling $\$ 407$ million in sales. These sales provided profits of $\$ 197$ million to the alcohol industry.

Alcohol frequently plays a role in these adverse outcomes and the human tragedies they produce. Among the most prominent adverse consequences of underage alcohol use are those listed below. ${ }^{2}$

\section{Approximately: ${ }^{2}$}

Annually, about 5,000 people under age 21 die from alcohol-related injuries involving underage drinking.

- $\quad 1,900$ (38 percent) of the 5,000 deaths involve motor vehicle crashes,

- $\quad 1,600$ (32 percent) result from homicides, and

- $\quad 300$ (6 percent) result from suicides. ",2

\section{Underage Drinking}

- $\quad$ "Underage drinking plays a significant role in risky sexual behavior, including unwanted, unintended, and unprotected sexual activity, and sex with multiple partners." It also:

- $\quad$ Increases the risk of physical and sexual assault.

- Is associated with academic failure.

- Is associated with illicit drug use.

- Is associated with tobacco use. 
- $\quad$ Can cause a range of physical consequences.

- Can cause alterations in the structure and function of the developing brain.

- Creates secondhand effects that can put others at risk. Loud and unruly behavior, property destruction, unintentional injuries, violence, and even death because of underage alcohol use afflict innocent parties. For example, about 45 percent of people who die in crashes involving a drinking driver under the age of 21 are people other than the driver.

- $\quad$ Is a risk factor for heavy drinking later in life.

High Prevalence of Alcohol Use Disorders Among the Young

"Figure 2 shows that the highest prevalence of alcohol dependence is among people ages 18-20."

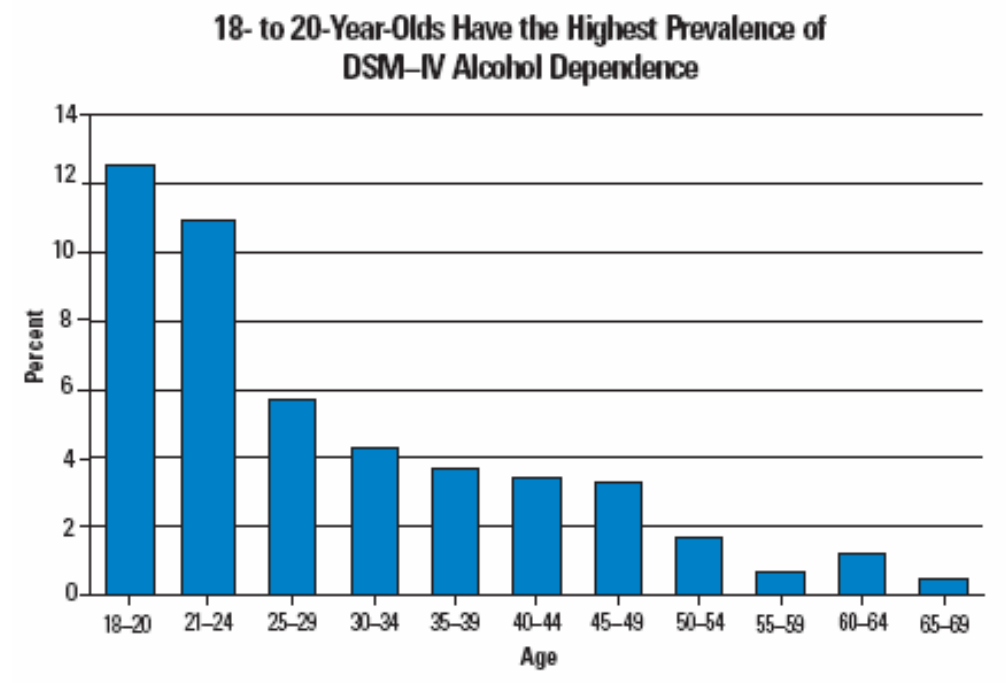

Figure 2: Prevalence of Past-Year DSM-IV Alcohol Dependence-U.S.

Source: Grant et al. 2004 (data from the National Epidemiologic Survey on Alcohd and Related Conditions)

"In other words, the description these young people provide for their drinking behavior meets the criteria for alcohol dependence set forth in the most recent editions of the Diagnostic and Statistical Manual of Mental Disorders."

\section{Negative Consequences of Alcohol Use on College Campuses Are Widespread}

"Studies consistently indicate that about 80 percent of college students drink alcohol, about 40 percent engage in binge drinking, and about 20 percent engage in frequent episodic heavy consumption, which is bingeing three or more times over a two-week period." More statistics are:

- $\quad$ An estimated 1,700 college students between the ages of 18 and 24 die each year from alcohol-related unintentional injuries, including motor vehicle crashes."

- $\quad$ Approximately 600,000 students are unintentionally injured while under the influence of alcohol.

- $\quad$ Approximately 700,000 students are assaulted by other students who have been drinking.

- $\quad$ About 100,000 students are victims of alcohol-related sexual assault or date rape.

"According to the 2006 National Survey on Drug Use and Health, an estimated 10.2 million people age 12 and older reported driving under the influence of illicit drugs during the year prior to being surveyed.",3 


\section{A Snapshot of Annual High-Risk College Drinking Consequences ${ }^{4}$}

"The consequences of excessive and underage drinking affect virtually all college campuses, college communities, and college students, whether they choose to drink or not."

- Death: 1,700 college students between the ages of 18 and 24 die each year from alcohol-related unintentional injuries, including motor vehicle crashes.

- Injury: 599,000 students between the ages of 18 and 24 are unintentionally injured under the influence of alcohol.

- $\quad$ Assault: More than 696,000 students between the ages of 18 and 24 are assaulted by another student who has been drinking.

- Sexual Abuse: More than 97,000 students between the ages of 18 and 24 are victims of alcohol-related sexual assault or date rape."

- Unsafe Sex: 400,000 students between the ages of 18 and 24 had unprotected sex and more than 100,000 students between the ages of 18 and 24 report having been too intoxicated to know if they consented to having sex.

- $\quad$ Academic Problems: About 25 percent of college students report academic consequences of their drinking including missing class, falling behind, doing poorly on exams or papers, and receiving lower grades overall.

- Health Problems/Suicide Attempts: More than 150,000 students develop an alcohol-related health problem and between 1.2 and 1.5 percent of students indicate that they tried to commit suicide within the past year due to drinking or drug use.

- Drunk Driving: 2.1 million students between the ages of 18 and 24 drove under the influence of alcohol last year.

- Vandalism: About 11 percent of college student drinkers report that they have damaged property while under the influence of alcohol.

- Property Damage: More than 25 percent of administrators from schools with relatively low drinking levels and over 50 percent from schools with high drinking levels say their campuses have a "moderate" or "major" problem with alcohol-related property damage.

- $\quad$ "Police Involvement: About five percent of four-year college students are involved with the police or campus security as a result of their drinking and an estimated 110,000 students between the ages of 18 and 24 are arrested for an alcohol-related violation such as public drunkenness or driving under the influence.

- Alcohol Abuse and Dependence: 31 percent of college students met criteria for a diagnosis of alcohol abuse and 6 percent for a diagnosis of alcohol dependence in the past 12 months according to questionnaire-based self-reports about their drinking.

\section{Doing Our Part}

Based upon the aforementioned research and statistics, there is clearly a huge problem with our youth making the wrong decisions regarding the use of alcohol and illegal drugs. Therefore, we attempt to highlight the negative factors that will affect our audience personally, in hopes of reinforcing what parents, teachers and DARE programs have already attempted to do: it is wrong, it is illegal and if you insist on making the wrong decisions, there are consequences for your actions.

Thus, we use our knowledge and background to enlighten them on the ramifications of common types of results for being arrested for driving while intoxicated, possession or consumption of alcohol or drugs, and destructive behaviors. These include:

1. arrest

2. punishment

3. financial costs

4. social costs

5. long lasting effects 
With each one of these enumerated items, we provide actual case scenarios from our positions as Municipal Prosecutor and Judge. We try to do so to reinforce positive behaviors and to "shock their consciousness" that it is not always the "other guy" who gets caught, but that the decisions they are making now will indeed affect them for the rest of their lives.

\section{Is It Working?}

We have been providing this legal education to the Freshman Seminar students in our area for the past five years. Of course, we would like to think that we are making a difference in their choices and have prevented all of the students that we have presented to from doing anything wrong and have saved their lives from death, injury, financial and social ruin and a disappointing phone call to parents stating they need bond money. But have we?

Quite honestly, we have had no measurable way to make such a statement or a determination as to what portion of these students such a presentation has really had a positive effect on them.

Consequently, this year we decided to try and evaluate our efforts with the use of a short survey that asks just a few questions about their previous behaviors and attitudes to see if our presentation has affected them in the manner that we intended. Following is Exhibit One, which is a copy of the evaluation instrument to be used in the Freshman Seminar presentation. As you can see, with the use of a Lickert Scale, we hope to be able to more accurately determine the effectiveness of the presentation. If we do find it has a positive outcome on the students, one of our plans is to offer the legal presentation campus-wide as part of the university's Freshman Seminar curriculum.

\section{CONCLUSION}

Social responsibility is an often-used term to describe a variety of activities. One of those activities, we believe, is the ability to use our education and experiences to share with others for the benefit of society. Faculty members are in a unique position to be able to become involved in these important roles and we believe they should take a proactive approach in doing so.

We have shared with you our approach to helping young men and women try to make the right decisions and choices to help them both now and in their future endeavors. We hope this "sparks your interest" as well and that you design a way to become involved in making your communities a better place to live and thus become a part of the Social Responsibility Movement.

\section{AUTHOR INFORMATION}

Dr. J. Patrick McLaughlin, Professor of Accounting, Economics and Finance, has taught Law and Insurance courses at Northwest Missouri State University since 1978. He is a practicing attorney, Municipal Judge and Prosecuting Attorney. He received his J.D. degree from the University of Missouri at Kansas City and his B.S.B.A. degree from the University of Central Missouri. Dr. McLaughlin has also received numerous Best Research Paper Awards and Excellence in Teaching Awards, including the Governor's Award and Dean's Award.

Dr. John W. Baker, Jr., Associate Professor in the Department of Accounting, Economics and Finance has taught Law and Taxation courses at Northwest Missouri State University since 1977. He is a practicing attorney and the Maryville Municipal Judge. He received his LLM, J.D. and M.B.A. degrees from the University of Missouri, Kansas City and his B.S. degree from Rockhurst University.

\section{ENDNOTES}

1. Pacific Institute for Research and Evaluation (PIRE). (October 2006). Underage drinking in Missouri: The facts. Retrieved October 25, 2008, from http://www.iiaaonline.org/pdf/MO_Underage.pdf

2. The Center on Alcohol Marketing and Youth. (2007). Consequences of underage drinking. Retrieved October 21, 2008, from http://camy.org/factsheets/print.php?FactsheetID=29 
3. National Institutes of Health: National Institute on Drug Abuse. (April 2008). Info facts: Drugged driving. Retrieved October 21, 2008, from http://www.drugabuse.gov/PDF/Infofacts/driving08.pdf

4. National Institutes of Health: National Institute on Alcohol Abuse and Alcoholism. (July 11, 2007). A snapshot of annual high-risk college drinking consequences. Retrieved October 28, 2008, from http://www.collegedrinkingprevention.gov/StatsSummaries/snapshot.aspx

\section{EXHIBIT ONE}

\section{Presentation Evaluation Freshman Seminar}

It has been a pleasure providing you with legal information that will hopefully help make your transition to college life less stressful, costly and potentially cause you problems throughout your life.

We now ask that you do something for us. Please fill out the following brief questionnaire with your honest perceptions and thoughts on what you have heard today. It is anonymous, but will help us determine if your actual perceptions have changed after the presentation.

Dr. John W. Baker, Jr.

Maryville Municipal Judge

Please circle your answers.
Dr. J. Patrick McLaughlin

Maryville Municipal Prosecuting Attorney

1. Before today's presentation, regarding alcohol I would:

$\begin{array}{lllll}2 & 1 & 0 & -1 & -2 \\ -\begin{array}{l}\text { Definitely not } \\ \text { drink as a minor }\end{array} & \begin{array}{l}\text { Probably not drink } \\ \text { as a minor }\end{array} & \begin{array}{l}\text { Not sure if } \\ \text { I would drink }\end{array} & \begin{array}{l}\text { Probably } \\ \text { drink as a } \\ \text { minor }\end{array} & \begin{array}{l}\text { Definitely } \\ \text { drink as a minor }\end{array}\end{array}$

2. Before today's presentation, regarding illegal drugs I would:

\begin{tabular}{|c|c|c|c|c|}
\hline 2 & 1 & 0 & -1 & -2 \\
\hline $\begin{array}{l}\text { Definitely not } \\
\text { try, even if } \\
\text { available }\end{array}$ & $\begin{array}{l}\text { Probably not } \\
\text { try, even if } \\
\text { available }\end{array}$ & $\begin{array}{l}\text { Not sure if } \\
\text { I would try if } \\
\text { available }\end{array}$ & $\begin{array}{l}\text { Probably try } \\
\text { if available }\end{array}$ & $\begin{array}{l}\text { Definitely try } \\
\text { if available }\end{array}$ \\
\hline
\end{tabular}

3. After today's presentation, regarding alcohol I would:

\begin{tabular}{lllll} 
& 1 & 0 & -1 & -2 \\
\hline $\begin{array}{l}\text { Definitely not } \\
\text { drink as a minor }\end{array}$ & $\begin{array}{l}\text { Probably not drink } \\
\text { as a minor }\end{array}$ & $\begin{array}{l}\text { Not sure if } \\
\text { I would drink }\end{array}$ & $\begin{array}{l}\text { Probably } \\
\text { drink a } \\
\text { minor }\end{array}$ & $\begin{array}{l}\text { Definitely } \\
\text { drink as a minor }\end{array}$
\end{tabular}

4. After today's presentation, regarding illegal drugs I would:

\begin{tabular}{|c|c|c|c|c|}
\hline $\begin{array}{l}\text { Definitely not } \\
\text { try even if } \\
\text { available }\end{array}$ & $\begin{array}{l}\text { Probably not } \\
\text { try, even if } \\
\text { available }\end{array}$ & $\begin{array}{l}\text { Not sure if } \\
\text { I would try if } \\
\text { available }\end{array}$ & $\begin{array}{l}\text { Probably try } \\
\text { if available }\end{array}$ & $\begin{array}{l}\text { Definitely try } \\
\text { if available }\end{array}$ \\
\hline
\end{tabular}


5. After today's presentation, I found the information:

\begin{tabular}{|c|c|c|c|c|}
\hline 2 & 1 & 0 & -1 & -2 \\
\hline $\begin{array}{l}\text { Would definitely } \\
\text { tell my friends } \\
\text { about these issues } \\
\text { to help them, too }\end{array}$ & $\begin{array}{l}\text { Would probably } \\
\text { tell my friends } \\
\text { about these issues } \\
\text { to help them, too }\end{array}$ & $\begin{array}{l}\text { Ok, but not really } \\
\text { sure I learned } \\
\text { much new }\end{array}$ & $\begin{array}{l}\text { Informative, but } \\
\text { would not discuss } \\
\text { with my friends }\end{array}$ & $\begin{array}{l}\text { A total waste } \\
\text { of my time }\end{array}$ \\
\hline
\end{tabular}

I am a: $\quad$ Female $\quad$ Male

I drank alcohol before college: $\quad$ Yes $\quad$ No

I tried illegal drugs before college: $\quad$ Yes $\quad$ No

If the punishments discussed in today's presentation are not severe enough to deter you from drinking alcohol as a minor, taking illegal drugs or driving while intoxicated, what punishments do you believe would be necessary to prevent you from engaging in these actions?

When complete, please put in box in the front of the room.

THANK YOU! 


\section{$\underline{\text { NOTES }}$}

